\title{
The Cranial Metastases in Angiosarcoma
}

\section{Anjiyosarkomda Beyin Metastazı}

\author{
Yasemin Benderli Cihan
}

Kayseri Eğitim Ve Araştırma Hastanesi, Radyasyon Onkoloji, Kayseri, Türkiye

DOI: $10.5505 /$ aot.2012.44153

Anahtar Kelimeler: Anjiyosarkom; Beyin metastazı; Erişkin

Key words: Angiosarcoma; Cranial metastasis; Adult

\section{Sayın Editör,}

Beyin metastazı anjiyosarkomda nadir görülür. Anjiyosarkomlar, damar endotelinden çıkan ve damar yapısını taklit eden, nadir rastlanan malign vasküler tümörlerdir (1). En sık ekstremite, deri yumuşak doku, göğüs ve karaciğerde görülmektedir (2,3). Anjiyosarkomlarda tercih edilen tedavi yöntemi lezyonun tümüyle çıkartılmasıdır. Radyoterapi (RT) ve kemoterapi, ek tedavi yöntemleri olarak kullanılmaktadır (4,5). Anjiyosarkom tanis1 alan olgularin \%60'inda tanis1 konulduğu anda metastaz bulunmaktadır. Beyin metastazı ise olguların \%1'inden azında görülmektedir $(2,5)$.

Sağ ayağında iki aydır şişlik şikâyeti 85 yaşında erkek hastaya anjiyosarkom tanısı konuldu. Yapılan tetkiklerinde akciğer metastazı saptanan hastaya haloksan ve adriyamisin başlandi. Kemoterapi sonrası değerlendirmede akciğerdeki lezyonlarda minimal azalma tespit edildi. Hasta, tedavisi tamamlandiktan bir ay sonra bayılma, konvülziyon şikâyetleri ile başvurdu. Çekilen beyin bilgisayarlı tomografisinde sağ pariyetal ve sol pariyeto-oksipital bölgede loblarda en büyüğü $2 \mathrm{~cm}$ boyutunda olmak üzere hiperintens lezyonlar ve etrafinda yoğun ödem saptand1 (Resim 1). Deksametazon 4x8 mg/gün ve Eptantoin 3x100 mg/gün başlandı. cinste de

Anjiyosarkom, anaplastik ve atipik hücreler içeren, endotel hücrelerinin oluşturduğu kitlelerden oluşan, damar orjinli malign bir neoplazmdir.

Tüm vasküler tümörlerin önemsenmeyecek derecede küçük bir oranını teşkil etmektedir (1-3). Her yaşta ve her iki Her yaşta ve her iki cinste de oluşabilir.
Pik insidansına altıncı ve yedinci dekatlarda ulaşmaktadır. Operasyon düşünül-meyen hastaya acil kraniyal RT başlandı. Anjiyosarkom prognozu oldukça hizlı olup, hastalar genellikle 1 y1l içinde kaybedilir (5).

Sonuç olarak anjiyosarkomda beyin metastazı nadir olup çoğunlukla akciğer metastazı ile birlikte veya takiben görülmektedir. Beyin metastazı olan olgularda uygulanan metastazektominin sağkalıma fazla katkıs1 yoktur. Nörolojik semptomları olan hastaların beyin metastazı olabileceği düşünülmeli ve bu yönde değerlendirilmelidir.

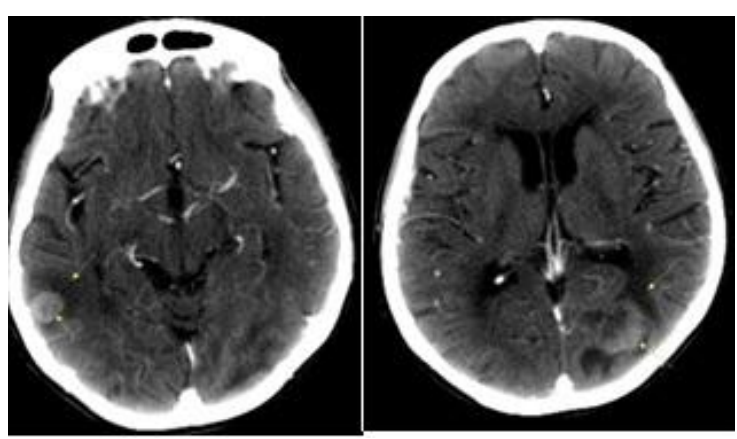

Resim 1: Sağ paryetal ve sol paryeto-oksipital bölgede kortikomedüller yerleşimli belirgin kontrast tutan periferinde ödem etkisi olan intraaksiyel kitle lezyonu izlenmektedir (Bilgisayarlı tomografi, oklar).

\section{Çıkar Çatışması: Yok}

\section{Kaynaklar}

1. Robbins SL, Cotran RS, Kumar V. Pathologic basis of disease. 1984; WB Saunders Company: p. 542-3

2. Meis-Kindblom JM, Kindblom LG. Angiosarcoma of soft tissue: a study of 80 cases. Am J Surg Pathol 1998;22:683-9

3. Weiss WS, Goldblum RJ. Malignant Vascular Tumors. In: Weiss WS, Goldblum RJ. Soft Tissue Tumors. St.Louis: Mosby Inc. 2001; p.917-52 
4. Enzinger FM, Weiss SW. Soft tissue tumors. 3rd ed. Mosby St. Louis. 1995;656-7
5. Maddox JC, Evans HL. Angiosarcoma of skin and soft tissue: a study of 44 cases. Cancer 1981;48:1907

Address for Correspondence: Uzm. Dr. Yasemin Benderli Cihan, Hastane Cad. Kayseri - Türkiye 